MODELING, IDENTIFICATION AND CONTROL, 1981, voL. 2, NO. 3, 163-179

doi: $10.4173 /$ mic.1981.3.2

\title{
The impact of phosphorus load and water through-flow on phytoplankton standing crop in a dimitic lake $\dagger$
}

\author{
KNUT LEHRE SEIP $\ddagger$
}

Keywords: phosphorus, phytoplankton, eutrophication, ecosystem, lake, management, modelling, simulation.

A mathematical model has been developed for the mesotrophic Lake Mjøsa $\left(365 \times 10^{6} \mathrm{~m}^{2}, 61^{\circ} \mathrm{N}, 11^{\circ} \mathrm{E}\right)$. Emphasis has been made on the interaction between biological and hydrodynamic variables. Simulation results for phytoplankton and nutrient concentrations in both the epilimnion and the hypolimnion compare fairly well with observations. Investigative simulations have been made to study the effects of injecting nutrients at different depths assuming three alternative schemes for diffusion across the thermocline. The overall results indicate that the phytoplankton standing crop is less sensitive to nutrient injection depths when diffusion increases, and that the high efficiency of hypolimnetic injection reported for some lakes in the literature will not be obtained in the present lake. Simulation studies of changes in river flow indicate that changes in peak flow time (inside the domain of natural variability) have a greater impact on the phytoplankton standing crop $(<20 \%)$ than changes in flow volume $(<6 \%)$. Simulations also indicate that light extinction caused by suspended particles associated with river flow may be important in sections of the lake.

\section{Introduction}

The present simulation study is an investigative effort to examine how nutrient discharge and river regulation may affect the water quality of Lake Mjøsa $\left(61^{\circ} \mathrm{N}\right.$, $11^{\circ} \mathrm{E}$ ) in Norway. The study is part of a programme for the assessment of a proposed regulation of the main tributary. Nutrient load, river through-flow, vertical mass exchange, turbidity and zooplankton grazing have been introduced as main topics of the study because these factors are believed to affect strongly the state of the present ecosystem. For example, river water, low in total phosphorus, may dilute both the nutrient and phytoplankton content of the lake water. The river also carries a considerable amount of suspended particles which decreases the light penetration in the water column and thus may decrease the phytoplankton production even further. When then, will be the synergistic effect of both dilution and light extinction?

The model is fairly simple. It is intended only as a conceptual framework for the discussion of large-scale processes $(\simeq 10 \mathrm{~km}$ horizontally $\times 10 \mathrm{~m}$ vertically) and can be looked upon as an extension of the budget model used for Lake Mjøsa by Holtan (1978).

When comparing the present results to earlier presentations of Lake Mjøja simulations (Seip $1980 \mathrm{a}, \mathrm{b}$ ), note that the following changes have been made. Representation of lake morphology has been changed and new data for phosphorus load have been used. In previous calculations we probably overstimated the exchange processes between epilimnion and hypolimnion and have thus now used lower values.

Received 3 December 1980.

† This project was financed by the Royal Norwegian Council for Scientific and Industrial Research and the Norwegian Water Resources and Electricity Board.

‡ Central Institute for Industrial Research, Forskningsen 1, Osio 3, Norway. 


\section{System description}

Lake Mjøsa is a relatively large and deep dimitic lake. Key data and graphs for some characteristic features of the lake system are given in Table 1 (see Fig. 1 and Fig. 2 respectively). The lake is susceptible to wind stresses, especially in the NW/SE direction, and large internal waves (including seiches) with periods of 5-7 days may then dominate the temperature and flow conditions of the lake (Thendrup 1978).

The direct and second-order effects of the internal waves may be important for the phytoplankton production of the lake (Holtan 1978) and constructs describing these processes have therefore been included in the model.

\subsection{The thermocline}

The thermocline will usually be firmly established by mid July, at $10-20 \mathrm{~m}$ depth in the main basin of the lake, and then erode down to about $40 \mathrm{~m}$ during the stratified period which ends at mid November. Internal waves, having an amplitude up to $40 \mathrm{~m}$ at the extreme ends of the lake, may be superimposed on this downward trend.

\begin{tabular}{|c|c|c|c|c|}
\hline \multicolumn{2}{|c|}{$\begin{array}{l}\text { Geographic position } 61^{\circ} \mathrm{N}, 11^{\circ} \mathrm{E} \\
\text { Area } 365 \times 10^{6} \mathrm{~m}^{2} \\
\text { Volume } 56 \times 10^{9} \mathrm{~m}^{3} \\
\text { Max depth } 445 \mathrm{~m} \\
\text { Mean depth } 153 \mathrm{~m} \\
\text { Length/width ratio: approx. } 20 \\
\text { Average epilimnion depth: } 30 \mathrm{~m} \\
\text { Stratified period, approx. } \\
\text { June-November }\end{array}$} & \multicolumn{3}{|c|}{$\begin{array}{l}\text { Theoretical retention time: } \\
\text { approx. } 6 \text { years } \\
\text { Phosphorus load } 1976: 393 \times 10^{3} \mathrm{~kg} \\
\text { or about } 1 \mathrm{gP} / \mathrm{m}^{2} \\
\text { Phosphorus concentration } \\
\text { 19.5.1976: } 5 \times 10^{-6} \mathrm{KgOP} / \mathrm{m}^{3} \\
\text { Mean water flow: } 320 \mathrm{~m}^{3} / \mathrm{s} \\
\text { Max. total biomass } 1976: \\
4 \times 10^{-3} \mathrm{Jkg} / \mathrm{m}^{3}\end{array}$} \\
\hline \multicolumn{5}{|c|}{ Morphological parameters, box approximation for main basin } \\
\hline Parameter & Name & Unit & Value & References \\
\hline $\begin{array}{l}\text { Volume } \\
\text { Area } \\
\text { Depth } \\
\text { Depth, average } \\
\text { epilimnion }\end{array}$ & $\begin{array}{l}V \\
A \\
Z \\
Z\end{array}$ & $\begin{array}{l}\mathrm{m}^{3} \\
\mathrm{~m}^{2} \\
\mathrm{~m} \\
\mathrm{~m}\end{array}$ & $\begin{array}{l}3.0 \times 10^{10} \\
2 \cdot 2 \times 10^{8} \\
136 \\
30\end{array}$ & $\begin{array}{l}\text { See text } \\
\text { See text } \\
\text { See text } \\
\text { Thendrup } 1978\end{array}$ \\
\hline
\end{tabular}

Table 1. Lake Mjøsa data

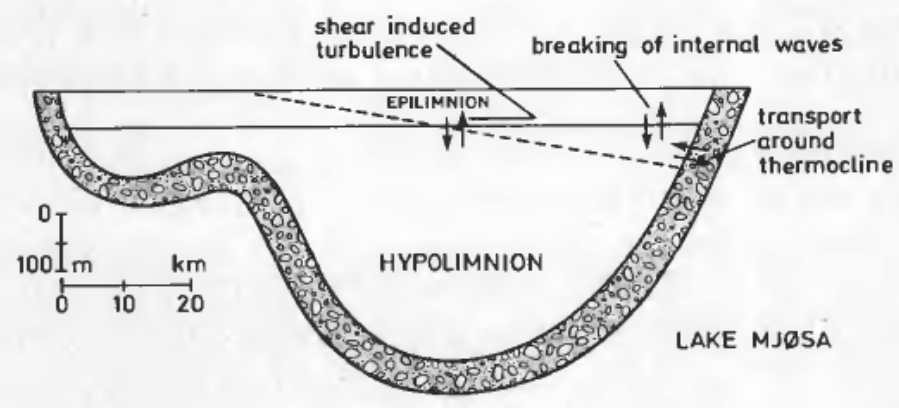

Figure 1. Lake Mjøsa cross section NW/SE. Mechanisms which potentially can give rise to vertical exchange processes are indicated. 

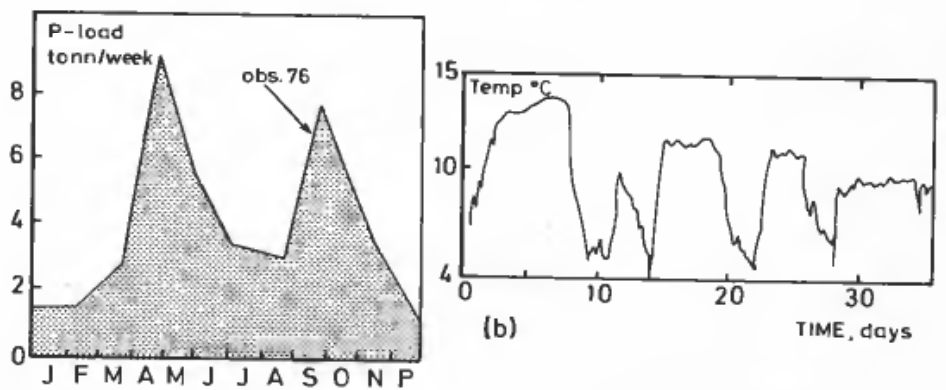

(o)
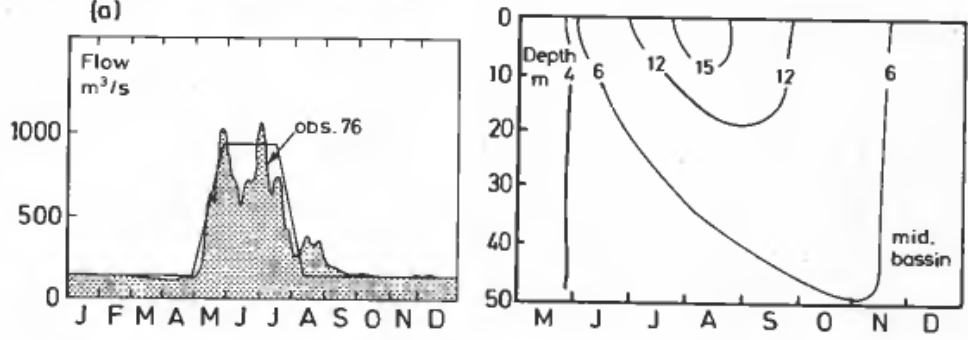

( c)

Figure 2. Lake Mjøsa driving functions. (a) Phosphorus load observed 1976. (b) Temperature measurements at $5 \mathrm{~m}$ depth in southern basin (internal waves). (c) River inflow. Observed 1976 and alternative approximation as forcing function. (d) Isothermal variations $\left({ }^{\circ} \mathrm{C}\right)$ in mid-basin.

Thermocline movements can be foreseen to influence phytoplankton production in at least three ways. They will allow the phytoplankton to reach different depths and thus experience different light regimes, and they may allow exchange of nutrients and plankton across the thermocline. Duton and Bryson (1962) indicate that transport of heat around the edges of the thermocline may be important for heat transport. It may also be important for nutrient transport 'around' the thermocline (see Fig. 1). The last two processes may be slosely related to the strength of the thermocline and to the forces damping the thermocline movements, e.g. breaking of the waves and shearinduced turbulence.

\section{Model description}

The emphasis of the model has been on a description of the interaction between hydrodynamic variables and phytoplankton production. The primary state variables are phosphorus available to phytoplankton, and the phytoplankton and zooplankton biomasses. A phosphorus budget is computed for horizontal layers of the lake and for the sediments. The basic model equations are given in Table 2 and details of the model in eqns. (3), (4) and (5).

Phytoplankton growth rate is limited by light, temperature and nutrients. Limitation by the two first factors is implemented by using piecewise linear functions of the abiotic factor value defining an optimal domain for the species (or for an aggregated functional group), and domains where growth rate decreases at higher and lower values of the abiotic factor considered. This formation allows independent characteristics to be given for limitation in the three domains, and the parameters are easily interpreted. 
Basic equations for the main model compartments. The set of equations (1)-(3) is used separately for epilimnion and hypolimnion.

(1) $\dot{N}=-\left[G_{\mathrm{p}}-D_{\mathrm{p}}\right] \cdot P+\left[(1-\mathrm{g}) G_{\mathrm{z}}+D_{\mathrm{z}}\right] \cdot Z+S_{N}{ }^{+}-S_{N}{ }^{-}$

(2) $\dot{P}=\left[G_{\mathrm{p}}-D_{\mathrm{p}}\right] \cdot P-G_{\mathrm{z}} \cdot Z+S_{\mathrm{p}}{ }^{+}-S_{\mathrm{p}}{ }^{-}$

(3) $\dot{Z}=\left[g \mathrm{G}_{\mathrm{z}}-D_{\mathrm{z}}\right] \cdot Z+S_{\mathrm{z}}{ }^{+}-S_{\mathrm{z}}{ }^{-}$

where

$N$ is nutrient (here phosphorus)

$P$ is phytoplankton biomass in phosphorus equivalents

$Z$ is zooplankton biomass in phosphorus equivalents

$G_{\mathrm{p}}$ is generalized growth rates for phytoplankton

$G_{\mathrm{z}}$ is zooplankton grazing rate

$D_{p}, D_{\mathrm{z}}$ are generalized mortality rates

$S^{+}, S^{-}$are terms for sources and sinks of the water segment considered

$g$ is the fraction of phytoplankton biomass grazed by zooplankton, and used for zooplankton growth

Table 2. The model equations.

Functions for phytoplankton growth and mortality:

(4) $G_{\mathrm{p}}=r_{0} \cdot R\left(g_{1} g_{2} \ldots g_{n}\right)$

(5) $D_{\mathrm{p}}=d_{1}+d_{2}+\ldots+d_{0}$

Modification of growth rate by abiotic factors

(6) $g_{i}=\operatorname{LI}\left[A_{\mathrm{c}}, T_{i, 1}, T_{i, 2}, O_{i, 1}, O_{i, 2}\right]$

Modification of growth rate by nutrient

(7) $g_{n}=\mathrm{MM}(N)$

(8) $\quad R=\min \left(g_{i}\right) \cdot \frac{1}{J-1} \sum_{i \neq i^{\prime}}^{J} g_{i}\left(i^{\prime}\right.$ corresponds to $\min \left(g_{i}\right), J=\max$. modifying factors)

(9) $\mathrm{MM}=$ a Michaelis-Menten form $=\left(N-N_{0}\right) /\left(N_{\mathrm{MM}}-N-N_{\mathrm{o}}\right)$

(10) $\mathrm{LI}=$ linear interpolation

where

$r_{0}$ is maximum growth rate

$g_{i}$ are factors modifying the growth rate

$d_{0}$ is a basic mortality rate, comparable to senescence

$d_{i}$ is additional mortality rates caused by abiotic factors etc.

$A_{\mathrm{c}}$ is current value of abiotic factor

$T_{i, 1}, T_{i, 2}$ is threshold values of abiotic factors below and above which no growth occurs

$O_{i, 1}, O_{i, 2}$ are lower and upper bound for optimal growth

$N$ is nutrient for species on next higher trophic level e.g. phosphorus for phytoplankton

$N_{0}$ is a minimum threshold level below which no nutrient uptake occurs

$N_{\mathrm{MM}}$ is half saturation coefficient for growth

Functions for zooplankton growth and mortality:

(11) $G_{\mathrm{z}}=\alpha \cdot \operatorname{MM}(P)$

(12) $D_{\mathrm{z}}=D_{\mathrm{e}}, D_{\mathrm{h}}$

where

$\alpha$ is zooplankton grazing rate

MM is a Michaelis-Menton form as before, but $P$ substitutes for $N$

$D_{\mathrm{e}}, D_{\mathrm{h}}$ is mortality of zooplankton in epilimnion and hypolimnion respectively

Table 3. Details of model equations. 
Nutrient uptake is given as a modified Michaelis-Menten formulation (cf. Di Toro 1980). Zooplankton grazing on phytoplankton is also given by a modified Michaelis-Menten formulation, but a fraction of the phytoplankton biomass is returned directly to the nutrient pool. Phytoplankton and zooplankton mortalities are given as constants. For nutrients, phytoplankton and zooplankton a lower limit of concentrations is set, indicating that at very low values of the respective quantities, mechanisms in the system prevent complete disappearance or extinction (e.g. some part of the phytoplankton assemblage will have very low sinking velocities or tolerate marginal abiotic conditions).

The thermocline is allowed to migrate according to a predefined schedule. The migration can be accompanied either by a complete water exchange between the two

Nutrients and phytoplankton input:

(13) $S^{+}=S_{1}{ }^{+}+S_{2}{ }^{ \pm}+S_{3}{ }^{+}+S_{4}{ }^{+}+S^{-}$

$S_{1}{ }^{+}=e \cdot N_{\text {flow }}$ is input from external sources like river inflow. (Data is given as a time variable input rate function)

$e$ is fraction of nutrient and phytoplankton to epiliminion

$S_{2}{ }^{ \pm}=N_{\text {ex }}$ is input from (output to) neighbouring water segment and is associated with water exchange. Corresponds to an apparent diffusion. The input may be chosen as a constant or proportional to the epilimnionvolume. A time variable component may be added.

$S_{3}{ }^{ \pm}=N_{\text {set }} / z$ is input from water segment above (output to water segment or sediment segment below). Sinking rate $N_{\text {sett }}$ is divided by the thickness $z$ of the considered segment.

$S_{4}{ }^{+}=N_{\text {rel }}$ is input from sediments (nutrients only) as fraction of sediment nutrient content.

$S_{2}{ }^{ \pm}=e \cdot e_{2} \cdot N / V$ is output associated with water outflow $e$ is as above

$e_{z}$ is varied only for zooplankton and is the fraction flushed out with river water. $e_{z}=1$ for phytoplankton

Table 4. Sources and sinks for each water segment.

$W \quad$ is water inflow

$T_{\mathrm{e}}, T_{\mathrm{h}} \quad$ is temperatures in epilimnion and hypolimnion respectively

(14) $I=I_{0} \cdot f_{1} \cdot f_{2} \cdot f_{3} \cdot f_{4}$ is average light intensity between depths $d_{1}$ and $d_{2}$

$I_{0} \quad$ is incident light, given as a sine function

(15) $f_{1}=\left[\exp \left(-\epsilon_{\mathrm{s}} d_{2}\right)-\exp \left(-\epsilon_{\mathrm{s}} \cdot d_{1}\right)\right] / \epsilon_{\mathrm{s}}\left(d_{2}-d_{1}\right)$ is reduction in light intensity caused by extinction in water column

(16) $\epsilon_{\mathrm{s}}=\epsilon_{1}+\epsilon_{2}+\epsilon_{3}$ is total extinction coefficient for water

(17) $\epsilon_{1}$ is a background extinction coefficient

$\epsilon_{2}=\beta \mathrm{P} \quad$ is extinction caused by self shading

(18) $\epsilon_{3}=\gamma e \cdot W / V$ is extinction associated with suspended particles in river water $d_{1}, d_{2}$ are water depths defining the water layer considered

(19) $f_{2}=1.0-k_{\mathrm{c} 1} C-k_{\mathrm{c} 2} \cdot C^{2}$ is reduction in light caused by average monthly cloud cover $C$

(20) $f_{3}=1.0-k_{\mathrm{w}} \cdot W I$ is reduction in light caused by wind $W I$

$f_{4} \quad$ is a factor adjusting for day length

$\beta, \gamma, k_{\mathrm{cl}}, k_{\mathrm{c} 2}, k_{\mathrm{w}}$ are constants (see Table 6)

Table 5. Driving functions, values found by interpolation in table of observations. 
columns or by water having unaltered properties flowing in horizontally from neighbouring lake segments. The first case may be appropriate for the long-term eroding of the thermocline, whereas case two may be characteristic for the effect of internal waves. In addition to the two schemes described above, a time variable amount of water may exchange between the two volumes, representing an apparent diffusion process.

\section{Database}

The data used in the model are obtained from reports on observations in Lake Mjøsa and from the literature. The data used and some literature values are given in Tables 6-8. For the data on fresh water species, we have chosen to make references to works which review several sources, to indicate the brackets for probable values. The data actually chosen for the present model are influenced by the type of model we develop, i.e. a simplified model for the large-scale dynamics of Lake Mjøsa. Thus we believe that extremely rapid processes which might take place, for example in a small enclosure, will not occur in this large body of water.

In the present model, the main basin of Lake Mjøsa has to be approximated by a box shape. We have chosen the area of the box so that the observed area depth curve is approximated most closely in the upper $40 \mathrm{~m}$ of the lake, because light extinction is an important process at these depths. The vertical size of the box is determined to give the approximate volume of the main basin.

\begin{tabular}{|c|c|c|c|c|c|}
\hline Parameter & Name & Unit & Value & $\begin{array}{l}\text { Literature } \\
\text { values }\end{array}$ & References \\
\hline $\begin{array}{l}\text { Waterflow, } \\
\text { average }\end{array}$ & $W$ & $\mathrm{~m}^{3} /$ day & $2 \cdot 77 \cdot 10^{7}$ & & Holtan 1978 \\
\hline Temperature & $T$ & & & & \\
\hline $\begin{array}{l}\text { epilimnion } \\
\text { hypolimnion }\end{array}$ & & $\begin{array}{l}{ }^{\circ} \mathbf{C} \\
{ }^{\circ} \mathbf{C}\end{array}$ & $\left.\begin{array}{l}0 \cdot 5-16 \cdot 5 \\
3 \cdot 8-5 \cdot 0\end{array}\right\}$ & & $\begin{array}{l}\text { Berge et al. } 1980 \\
\text { Tvede, personal }\end{array}$ \\
\hline Light intensity & $I_{0}$ & ly/day & $175-725$ & & $\begin{array}{l}\text { Norwegian } \\
\text { Meterological } \\
\text { Institute }\end{array}$ \\
\hline $\begin{array}{l}\text { Coefficients } \\
\text { related to } \\
\text { light reduction: }\end{array}$ & & & & & • \\
\hline $\begin{array}{l}\text { Extinction } \\
\text { coefficient }\end{array}$ & $\epsilon_{1}$ & $\mathrm{~m}^{-1}$ & $0 \cdot 2$ & $\begin{array}{l}0 \cdot 2-4 \cdot 0 \\
0 \cdot 3-2 \cdot 5\end{array}$ & $\begin{array}{l}\text { Wetzel } 1975 \\
\text { Megard } \text { et al. } 1980\end{array}$ \\
\hline Self-shading & $\beta$ & $\underset{\mathrm{Chl} \mathrm{a}}{\mathrm{m}^{-1} \cdot \mathrm{mg}_{1}{ }^{-1} / \mathrm{m}^{3}}$ & 0.02 & $\begin{array}{l}0.02-0.04 \\
0.0-22\end{array}$ & $\begin{array}{l}\text { Lorenzen } 1980 \\
\text { Megard } \text { et al. } 1979\end{array}$ \\
\hline $\begin{array}{l}\text { Turbidity } \\
\text { Cloud cover }\end{array}$ & $\begin{array}{l}\gamma \\
k_{\mathrm{c} 1} \\
k_{\mathrm{s} 2}\end{array}$ & day $m^{-1}$ & $\begin{array}{l}0 \cdot 70 \\
0 \cdot 38 \\
0 \cdot 38\end{array}$ & & $\begin{array}{l}\text { Discussed in text } \\
\text { Berliand } 1960\end{array}$ \\
\hline Wind speed & $k_{\mathrm{w}}{ }_{\mathrm{w}}$ & $\mathrm{s}^{-1} \cdot \mathrm{m}$ & 0.035 & & $\begin{array}{l}\text { Parsons and } \\
\quad \text { Takahashi } 1973\end{array}$ \\
\hline $\begin{array}{l}\text { Exchange } \\
\text { coefficient }\end{array}$ & $N_{\text {ex }}$ & $\mathrm{day}^{-1}$ & $0 \cdot 0-0 \cdot 05$ & $\begin{array}{l}0.001-0.01 \\
0.05\end{array}$ & $\begin{array}{l}\text { Imboden } 1974 \\
\text { Ebenhöh } 1980\end{array}$ \\
\hline
\end{tabular}

Table 6. Driving functions. 


\begin{tabular}{|c|c|c|c|c|c|}
\hline Parameter & Name & Unit & Value & $\begin{array}{l}\text { Literature } \\
\text { values }\end{array}$ & References \\
\hline \multicolumn{6}{|l|}{ Phytoplankton } \\
\hline $\begin{array}{l}\text { Max growth } \\
\text { rate }\end{array}$ & $r_{0}$ & $\mathrm{day}^{-1}$ & $2 \cdot 0$ & $\begin{array}{l}1 \cdot 0-2 \cdot 0 \\
2 \cdot 0-2 \cdot 5\end{array}$ & $\begin{array}{l}\text { Imboden } 1974 \\
\text { Scavia } 1980\end{array}$ \\
\hline $\begin{array}{l}\text { Optimal light } \\
\text { range }\end{array}$ & $\begin{array}{l}O_{1,1} \\
O_{1,2}\end{array}$ & Iy/day & $80 / 250$ & $\simeq 80 / 300$ & Reshkin and Knauer \\
\hline & & & & $\begin{array}{l}100 / 240 \\
250 / 300\end{array}$ & $\begin{array}{l}\text { Smith } 1980 \dagger \\
\text { Scavia } 1980\end{array}$ \\
\hline $\begin{array}{l}\text { Light } \\
\text { tolerance }\end{array}$ & $\begin{array}{l}T_{1,1} \\
T_{1,2}\end{array}$ & ly/day & $0 / 750$ & & \\
\hline $\begin{array}{l}\text { Optimal } \\
\text { temp. range }\end{array}$ & $\begin{array}{l}O_{2,1} \\
O_{2,2}\end{array}$ & ${ }^{\circ} \mathrm{C}$ & $20 / 25$ & $20 / 30$ & Scavia 1980 \\
\hline $\begin{array}{l}\text { Temperature } \\
\text { tolerance } \\
\text { range }\end{array}$ & $\begin{array}{l}T_{2,1}^{2,2} \\
T_{2,2}\end{array}$ & ${ }^{\circ} \mathrm{C}$ & $0 / 35$ & $/ 35$ & Scavia 1980 \\
\hline $\begin{array}{l}\text { Half } \\
\text { saturation } \\
\text { constant } \\
\text { for growth }\end{array}$ & $N_{\mathrm{MM}}$ & $\mathrm{mgP} / \mathrm{l}$ & 0.002 & $\begin{array}{l}0.004 \cdot 0.01 \\
0.00003- \\
0.0015\end{array}$ & $\begin{array}{l}\text { Scavia } 1980 \\
\text { Di Toro } 1980\end{array}$ \\
\hline Escape value & $N_{0}$ & $\mathrm{mgP} / \mathrm{l}$ & $0 \cdot 0$ & & \\
\hline Mortality & $D_{\mathrm{p}}$ & day $^{-1}$ & $0 \cdot 06$ & $\begin{array}{c}>0.05- \\
0.08\end{array}$ & $\begin{array}{l}\text { Scavia } 1980 \\
\text { Canale } \text { et al. } 1976\end{array}$ \\
\hline $\begin{array}{l}\text { Sinking } \\
\text { velocity } \\
\text { epilimnion }\end{array}$ & $N_{\text {sett }}, e$ & $\mathrm{~m} /$ day & $0 \cdot 6$ & $\begin{aligned} & 0 \cdot 6 \\
& 0 \cdot 1-0 \cdot 4 \\
& 0-0.05 \\
&<0 \cdot 1-3 \cdot 0 \\
& \\
& \\
& \text { neg. }-0 \cdot 43 \\
& \simeq 1 \cdot 0-3 \cdot 0\end{aligned}$ & $\begin{array}{l}\text { Prepas and Rigler } 1980 \\
\text { Imboden } 1974 \\
\text { Canale } \text { et al. } 1976 \\
\text { Schooner and Di Toro } \\
1980 \\
\text { Burns and Rosa } 1980 \\
\text { (organic detritus) } \\
\text { Burns and Rosa } 1980\end{array}$ \\
\hline $\begin{array}{l}\text { Sinking } \\
\text { velocity } \\
\text { hypolimnion }\end{array}$ & $N_{\text {sett }}, h$ & $\mathrm{~m} /$ day & $0 \cdot 6$ & & \\
\hline $\begin{array}{l}\text { Release from } \\
\text { sediments }\end{array}$ & $N_{\text {rel }}$ & day & 0 & & \\
\hline $\begin{array}{l}\text { Fraction to } \\
\text { each water } \\
\text { segment }\end{array}$ & $e$ & & variable & & \\
\hline \multicolumn{6}{|l|}{ Zooplankton } \\
\hline $\begin{array}{l}\text { Nutrient } \\
\text { utilization } \\
\text { rate }\end{array}$ & $g$ & day $^{-1}$ & $0 \cdot 4$ & 0.4 & Ebenhöh 1980 \\
\hline Grazing rate & $\alpha$ & day $^{-1}$ & $0 \cdot 8$ & $\begin{array}{c}1 \cdot 2-1 \cdot 8 \\
0 \cdot 7\end{array}$ & $\begin{array}{l}\text { Scavia } 1980 \\
\text { Ebenhöh } 1980\end{array}$ \\
\hline $\begin{array}{l}\text { Half } \\
\text { saturation } \\
\text { constant }\end{array}$ & $P_{\mathrm{MM}}$ & $\mathrm{mgP} / 1$ & varied & $0.06-0.6$ & Bacca et al. 1977 \\
\hline $\begin{array}{l}\text { Threshold } \\
\text { value }\end{array}$ & $P_{0}$ & $\mathrm{mgP} / \mathrm{l}$ & $0 \cdot 001$ & $0 \cdot 001-0 \cdot 02$ & Scavia 1980 \\
\hline $\begin{array}{l}\text { Mortality } \\
\text { epilimnion }\end{array}$ & $D_{\mathrm{e}}$ & $\mathrm{day}^{-1}$ & $0 \cdot 05$ & $0.05-0.1$ & Scavia 1980 \\
\hline $\begin{array}{l}\text { Mortality } \\
\text { hypolimnion }\end{array}$ & $D_{\mathrm{h}}$ & day $^{-1}$ & 0.05 & & \\
\hline
\end{tabular}

† Estimated indirectly from reference.

Table 7. Nutrients, phytoplankton and zooplankton. 


\begin{tabular}{|c|c|c|c|}
\hline Entities & Value & $\begin{array}{l}\text { Literature } \\
\text { values }\end{array}$ & References \\
\hline & 0.0088 & $0.0088-0.01$ & \multirow{7}{*}{$\begin{array}{l}\text { Bacca et al. } 1977 \\
\text { Parsons and Takahashi } 1973 \\
\text { Smith } 1980 \text {, text } \\
\text { Parsons and Takahashi } 1973 \\
\text { Scavia } 1976 \\
\text { Parsons and Takahashi } 1973 \\
\text { Estimated from above } \\
\quad \text { references }\end{array}$} \\
\hline$C / P^{p}$ & & $17-35$ & \\
\hline $\mathrm{C} / \mathrm{Chl}$ a & 50 & $20-100$ & \\
\hline & & $23-79$ & \\
\hline$C / B_{p}$ & 0.53 & & \\
\hline$C / B_{z}$ & $0 \cdot 4$ & $0.35-0.45$ & \\
\hline $\mathrm{P} / \mathrm{Chl}$ a & variable & $\simeq 0.5-3.0$ & \\
\hline
\end{tabular}

Table 8. Stoichiometric ratios, based on weight.

The data for phytoplankton and zooplankton characteristics are the same for all simulations, except when the impact of zooplankton grazing is studied explicitly. The exchange processes between the epilimnion and hypolimnion, including sinking of phytoplankton and nutrients, are changed between the simulation series. A description of these changes will be given in each section.

\section{Model simulations}

\subsection{Phosphorus budget for the main basin}

In the first series of simulations we have studied how the model would reproduce a typical time series for the phytoplankton standing crop and for the overall phosphorus balance of the main basin of the lake. Observations have been available for the year 1976 and for this year a phosphorus budget has been worked out independently by Hans Holtan (1978) at the Norwegian Institute for Water Research.

During this first simulation series no exchange has been associated with the eroding of the thermocline, but an apparent diffusion process is added which corresponds to a constant daily vertical exchange across the thermocline of about $1 \%$ of the epilimnion volume averaged over the stratified period. The value corresponds to the maximum value given by Imboden (1974) for the summer stagnation period and was chosen because large lakes are susceptible to forces creating high apparent diffusion (Schindler et al. 1980). The sedimentation rate has also been given a high value and is computed in terms of a sinking velocity from data for the total fraction of phytoplankton sinking out of the photic zone given by Prepas and Rigler (1980). The same sinking rate has been assigned to both organic and inorganic phosphorus and in the epilimnion and the hypolimnion. Better estimates should be obtained for these values. For example, Schindler et al. (1980) quotes observations that phosphates added to the hypolimnion are especially susceptible to sedimenttion.

The first simulation results depicted in Fig. 3 (a) show phytoplankton biomass as a function of time. The results are compared to observations of phytoplankton biomass in the main basin of Lake Mjøsa. In Fig. 3 (b) are shown corresponding time series for orthophosphate. The correspondence between simulation results and observations is fairly good. In Fig. 4 we have depicted the phosphorus budget for the lake, during the stratified period, in a form which makes it comparable to the corresponding budget worked out by Holtan (1978). The bars representing the simulation results have been divided into an organic and an inorganic section. 

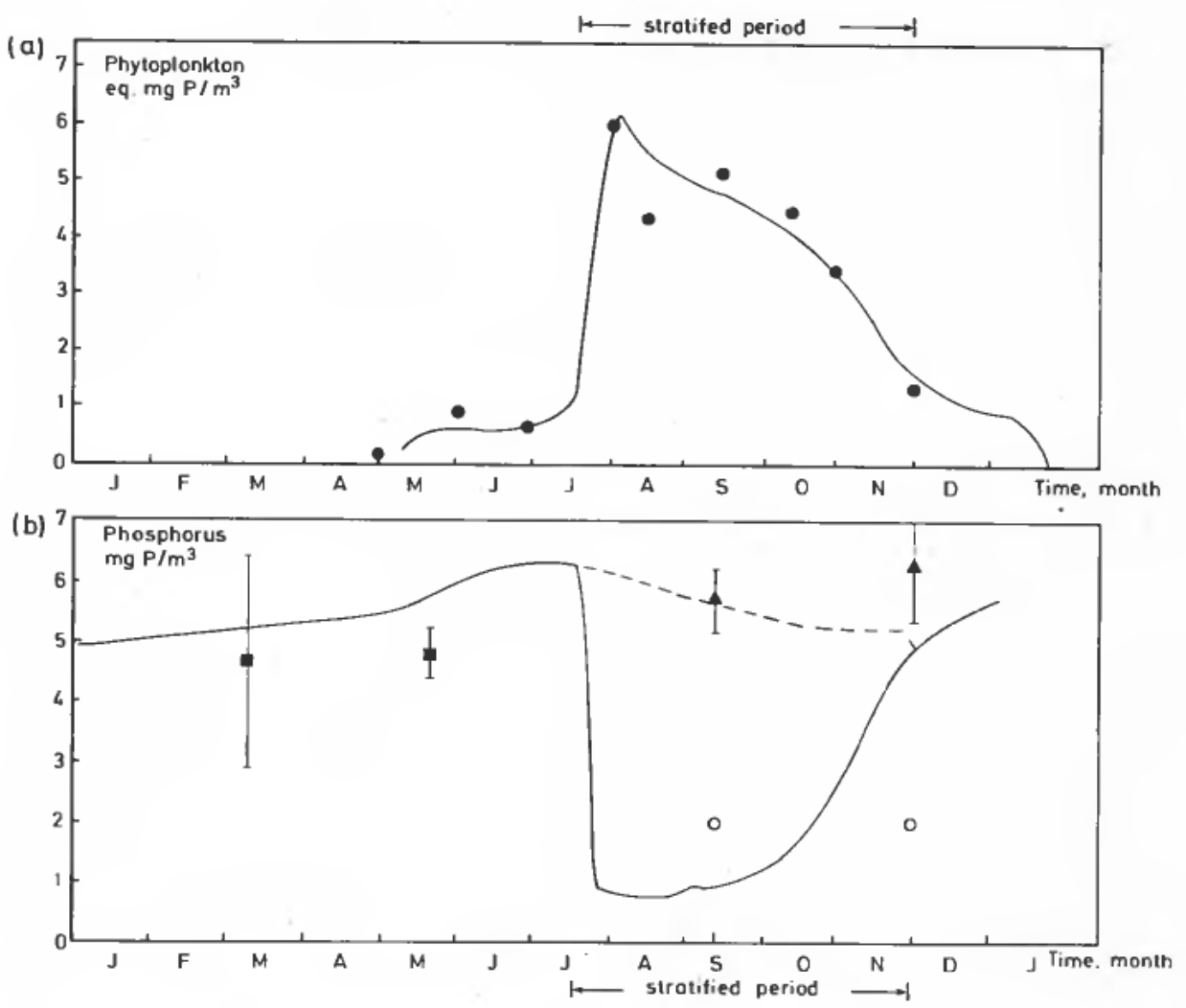

Figure 3. Comparisons between simulated and observed time series. (a) Phytoplankton in epilimnion as function of time. (b) Orthophosphate in epilimnion and hypolimnion as a function of time. - - Simulation results for well mixed period and for epilimnion in stratified period; - - - simulation results for hypolimnion in stratified period; - phytoplankton biomass, mixed samples from 0 to $10 \mathrm{~m}$ depth, observations were given as $\mathrm{g}$ biomass $/ \mathrm{m}^{3}$ but have been recomputed as equivalents of phosphorus bound by algae; $\boldsymbol{\Delta}$ orthophosphate in hypolimnion, computed as average value of all samples below thermocline; $\square$ orthophosphate in lake, computed as average value of samples from all depths; $O$ orthophosphate in epilimnion, computed as average value of samples above thermocline, $2 \mathrm{mg} / \mathrm{m}^{3}$ is detection limit; the bars represent the spread of sample values, from different depths, computed by standard deviation formulae. Data are from Holtan (1978), and personal communication.

The two budgets agree quite well and the differences are probably within the error range caused by uncertainties in the basic observations. An interpretation of time series and budget calculations can be found in Holtan (1978).

The agreement between simulated and observed results indicate that the main features of the system are reasonably well modelled. However, several features of the model and the data base are not tested adequately. For example, large errors in the sinking velocity of orthophosphate may not be detected because orthophosphate has very low concentrations in the epilimnion during the stratified period, and thus the simulation results may be insensitive to variations in sinking velocity during this period. 


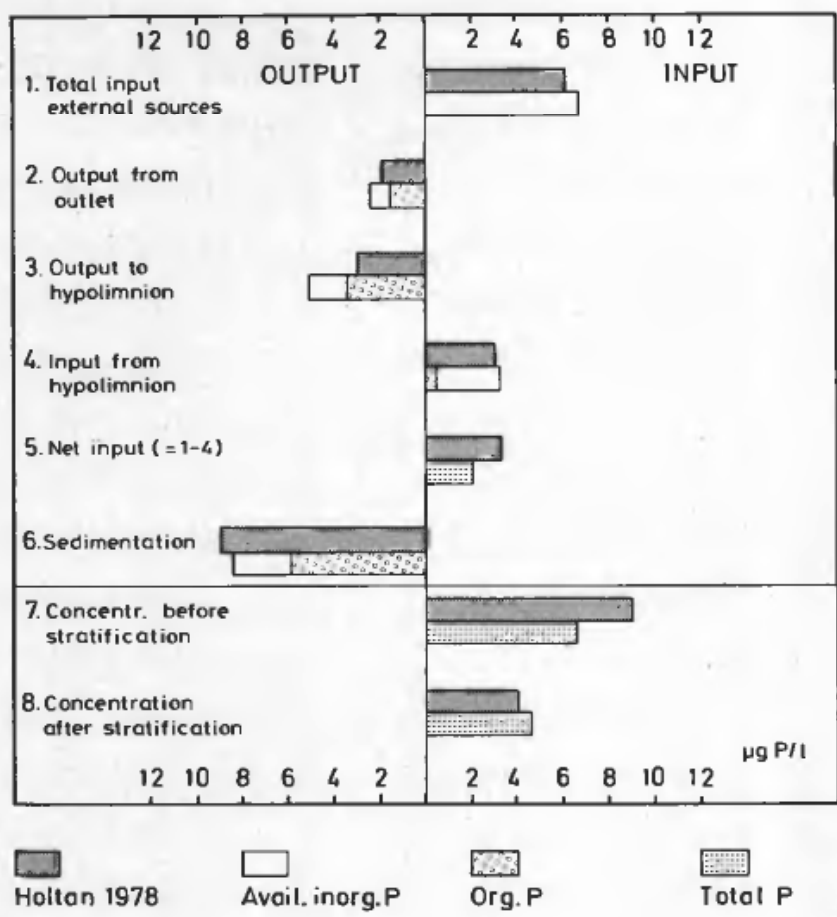

Figure 4. Net epilimnion budget showing the changes in concentration caused by different processes during the stratified period.

\subsection{Nutrient load and nutrient injection depths}

In the second simulation series we have studied the impact of nutrient load and nutrient injection depths on the phytoplankton biomass. In this particular simulation series the whole of Mjøsa was treated as one box and some preliminary estimates of the nutrient load were used as input. However, the main results and the conclusion are probably not affected.

In a preliminary simulation series we studied the effects of adding a constant diffusion term to the vertical exchange of water associated with a smoothly eroding thermocline. In Fig. 5 results are presented for three nutrient injection depths.

Nutrients are injected to the epilimnion $\left(N_{\mathrm{e}}=N_{\mathrm{t}}\right)$, to the hypolimnion $\left(N_{\mathrm{h}}=N_{\mathrm{t}}\right)$ and half of the nutrients are injected to each layer $\left(N_{\mathrm{e}} / N_{\mathrm{h}}=1 \cdot 0\right)$. (Exchange coefficients of 0.01 day $^{-1}$ and 0.05 day $^{-1}$ correspond at peak production time to hypolimnetic contributions to the nutrient pool of the epilimnion of about $0.5 \%$ and $10 \%$ respectively.)

It is seen that for small exchange coefficients the average biomass decreases with increasing coefficient except when nutrients are injected directly to the hypolimnion. An increase in diffusion between epilimnion and hypolimnion dilutes the phytoplankton, but feeds the epilimnion with nutrients, cf. Fig. 3 (a) and (b). For small exchange coefficients the effects of dilution are thus strongest when some nutrients are injected into the epilimnion, whereas the two effects nearly cancel when all the nutrients are injected into the hypolimnion. Larger values of the exchange coefficient increase the average biomass regardless of injection depth. 
For the next set of simulations three different assumptions regarding water exchange across the thermocline have been made. The first is intended to illustrate a situation with extreme water exchange. As the thermocline erodes from 20 to $40 \mathrm{~m}$ depth, a complete exchange of water between the two volumes is assumed. In addition an apparent diffusion is added corresponding to $5 \%$ daily exchange of water between

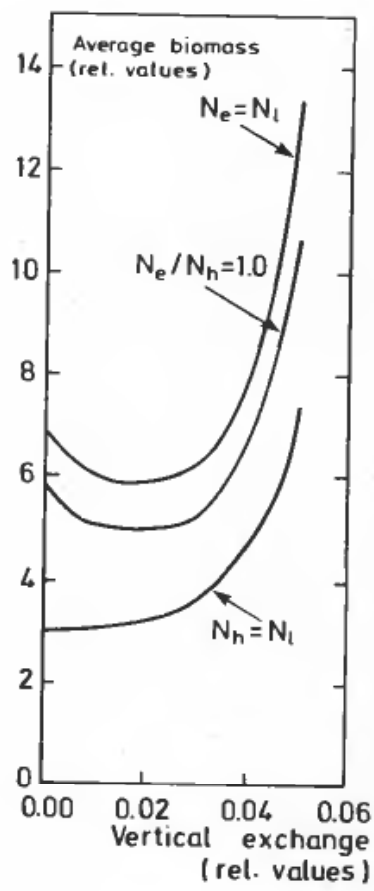

Figure 5. Average biomasses as a function of the exchange coefficient for different nutrient injection depths. $N_{\mathrm{t}}, N_{\mathrm{e}}, N_{\mathrm{h}}$ represents total nutrient load and load to epilimnion and hypolimnion respectively.

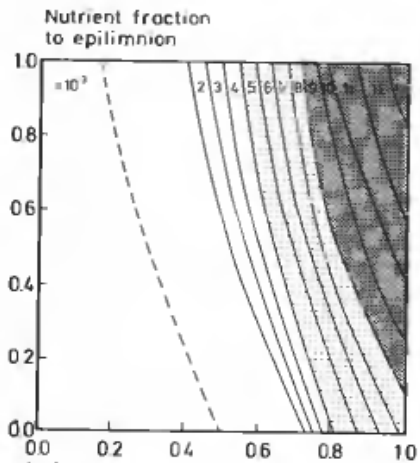

(a)

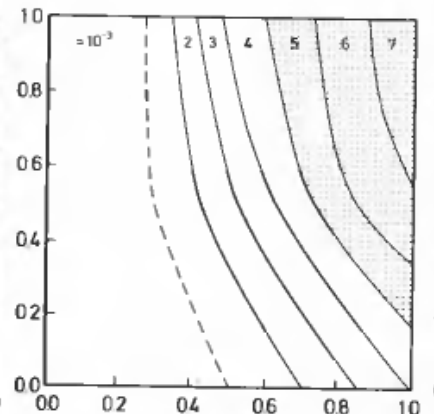

(b)

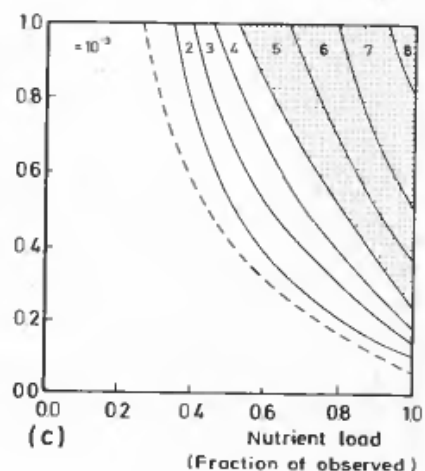

Increasing biomass (rel volues)

Figure 6. Iso-maps for average biomass. Biomass as a function of nutrient load and nutrient depths. (a) eroding thermocline with diffusion $(0 \cdot 05)$ added, $(b)$ injection eroding thermocline, $(c)$ no vertical exchange. 
epilimnion and hypolimnion. This value was used by Ebenhöh (1980) for his Barents Sea Model. In the next exchange scheme only the water exchange associated with an eroding thermocline is implemented and in the last scheme no water exchange occurs during the stratified period. The results are presented as 'iso maps' with nutrient load on the horizontal axis and fraction of nutrients to the epilimnion on the vertical axis. The overall results shown an increase in average phytoplankton biomass with increasing water exchange. (However, for water exchange coefficients $<0.02$ we showed in Fig. 5 that the biomass may decrease except when injection is not directly to the hypolimnion.) Figure 6 also shows that with full nutrient load extremely low phytoplankton biomasses are only obtained when there is no water exchange during the stratified period and when most of the phosphorus is injected to the hypolimnion. This last case can be compared with the results obtained by Schindler et al. (1980, Fig. 2). They showed that hypolimnetic injection in a small lake (about $0.5 \mathrm{~km}$ long) gives phytoplankton standing crop values $80-90 \%$ lower than a nearby lake fertilized at the surface.

\subsection{River flow changes}

In the last series of simulations we studied the impact of reduced river discharge or shift in time for the peak flow. Associated with river flow is also the effect of changes in light extinction as the river brings with it suspended particles. It has been proposed (Hamm and Kucklentz 1980) that different wash-out schemes for phytoplankton and zooplankton may affect phytoplankton productivity. During the following simulations an apparent diffusion of $1 \%$ of the average epilimnion volume constitutes the vertical exchange between epilimnion and hypolimnion.

In a first preliminary simulation series we investigated the effect of light extinction caused by suspended particles and grazing on the phytoplankton biomass by changing these factors at normal water flow conditions. Light extinction is given in the form of

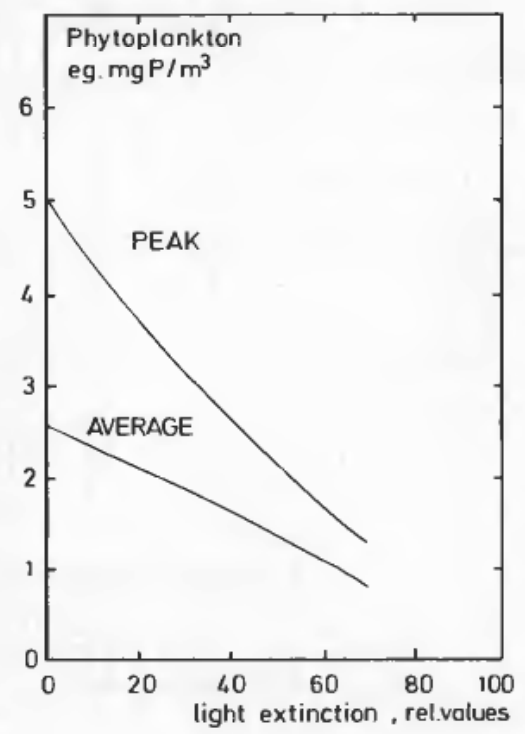

Figure 7. Phytoplankton biomass as a function of light extinction caused by suspended particles. Stratified period. Relative light extinction values are explained in the text. 
eqn. (18) in Table 5. The proportionality constant $\gamma$ was determined so that the extinction coefficient would range between 0 and 0.8 if the water flow reached peak value at maximum thermocline depth. The light extinction formulation presupposes that extinction changes instantly with river flow, and thus disregards the effects of a probable time lag.

In Fig. 7 is shown phytoplankton biomass as a function of light extinction. It is seen that light extinction may potentially decrease phytoplankton biomass considerably and peak values more than average values. However, suspended particles are not believed to contribute significantly to light extinction in the main basin of Lake Mjøsa (Holtan 1978).

Data for zooplankton in Mjøsa are not yet evaluated completely. During the years $1972-73$ a maximum of $8 \mathrm{~g} / \mathrm{m}^{2}$ dry weight was measured, corresponding to approximately $0 \cdot 15 \mathrm{~g} / \mathrm{m}^{3}$ wet weight or about $5 \%$ of maximum phytoplankton biomass. During the same years the peak in number of individual zooplanktons per square metre seems to coincide with the peak of phytoplankton. This may be a general feature of systems with low grazing pressure.

The general features (species composition and abundance) of the zooplankton community during the year 1976 is reported to be the same as in 1972-73 (Holtan 1977).

The impact of zooplankton grazing on phytoplankton biomass can be changed by varying several parameters as seen in eqn. (3), Table 2, eqns. (11) and (12), Table 3, and eqn. (13), Table 4. In Fig. 8 (a) are shown peak and average values of phytoplankton biomass as a function of the half-value constant for grazing, $\boldsymbol{P}_{\mathrm{MM}}$ and for
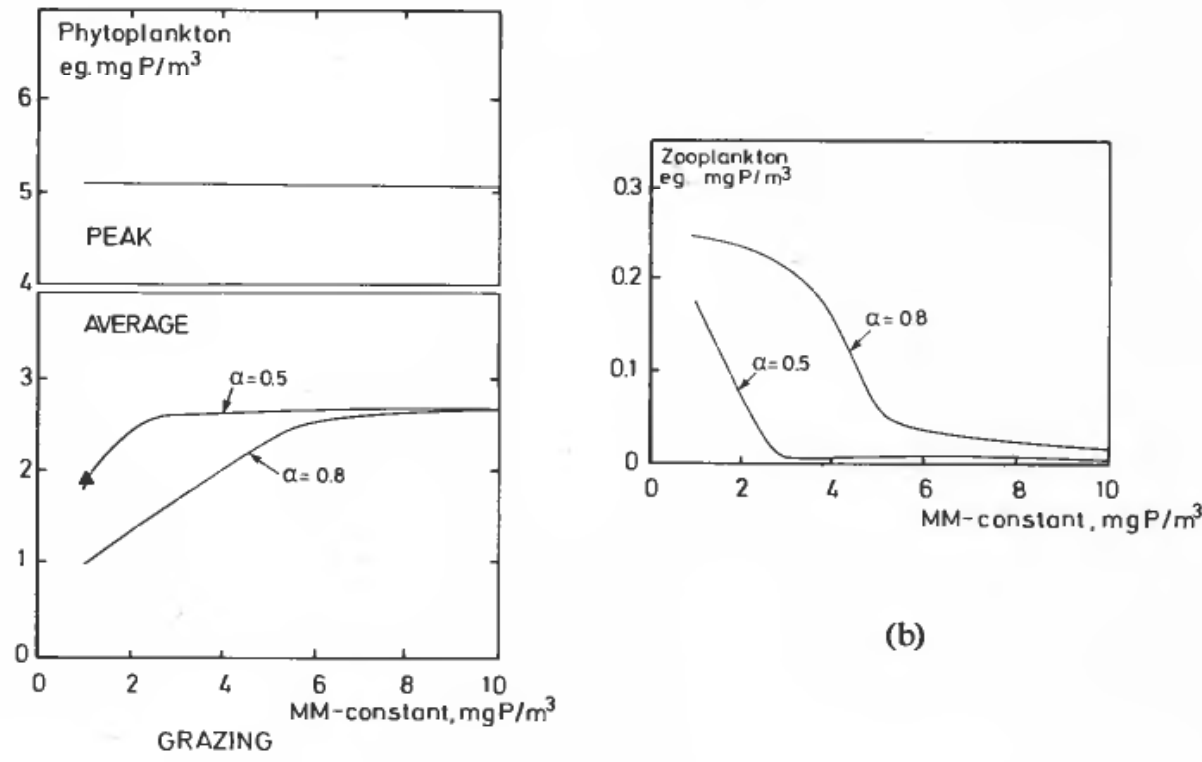

(a)

Figure 8. (a) Phytoplankton biomass as a function of zooplankton grazing. Stratified period. MM-constant is the half-saturation value of a Michaelis-Menten functional relationship between phytoplankton density and zooplankton grazing rate. $\alpha$ is maximum grazing rate as a fraction of zooplankton biomass. Thermocline decreasing from 20 to $40 \mathrm{~m}$ depth. Diffusion across the thermocline, but no water exchange associated with the decreasing thermocline. Zooplankton is washed out with river flow. (b) Zooplankton biomass as a function of zooplankton grazing rate. Stratified period. See text for explanation of units. 
two values of the fractional food intake parameter $\alpha$. The single result marked with a triangle is for the case where zooplankton is washed out with riverflow. In the other simulations no washing out occurs, and it is seen that this effect is not important for zooplankton in Lake Mjøsa. The corresponding values for zooplankton biomass are shown in figure $8(b)$. The rapid changes which can occur in a prey-predator system for critical values of parameter combinations is most easily seen in the this last figure. In the present examples, the average biomass during the stratified period decreases, whereas the peak value remains nearly constant for decreasing half-saturation constant.

In the following study, simulated river flow has been varied by multiplying the observed flow in 1976 with a constant fraction. Figure 9 shows resulting peak and average phytoplankton biomasses for three different thermocline schemes, $\mathrm{S}$ indicating an average shallow thermocline $(10-20 \mathrm{~m}), \mathrm{D}$ a deep thermocline $(20-40 \mathrm{~m})$, and $\mathrm{M}$ intermediate $(15-30 \mathrm{~m})$. The effect of water through-flow is greatest for the peak biomass occurring with a shallow thermocline. The shaded areas in Fig. 9 indicates approximate anticipated variations in total yearly flow volume (based on numbers reported by Holtan (1977) for the years 1973-76), and shows that a decrease in average water through-flow of $12 \%$ may give an increase in peak biomass of about $6 \%$. In Fig. $9(b)$ the impact of dilution has been studied, assuming that river flow is accompanied by suspended particles giving a maximum addition to light extinction of 0.4 . Within the same range of probable changes in total water flow a maximum increase in peak phytoplankton biomass of $16 \%$ may occur. Below we will study the effects of shifts of the time for peak river flow, keeping the total flow-volume constant.

In Fig. $9(c)$ is shown phytoplankton biomass as a function of fractional reduction in river flow for low and high grazing pressure. High grazing lowers the average

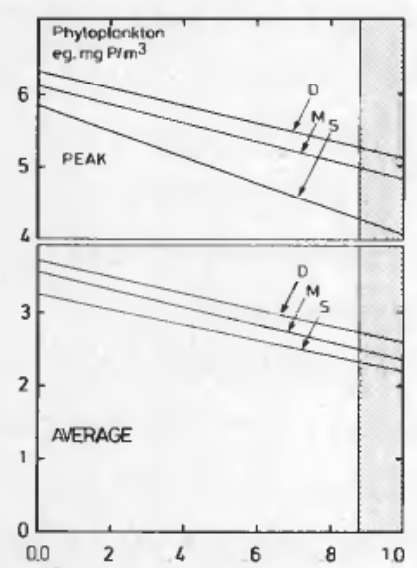

(a)

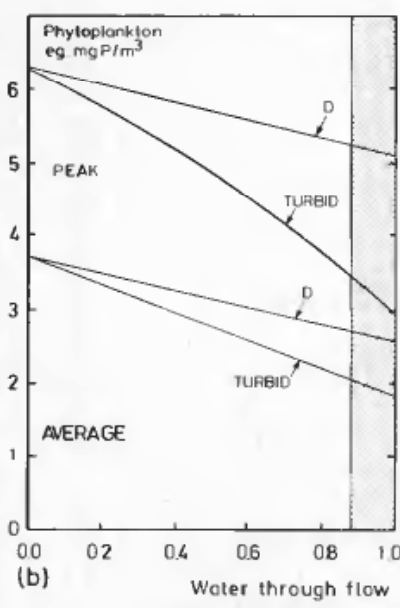

(Fractions of observed 1976

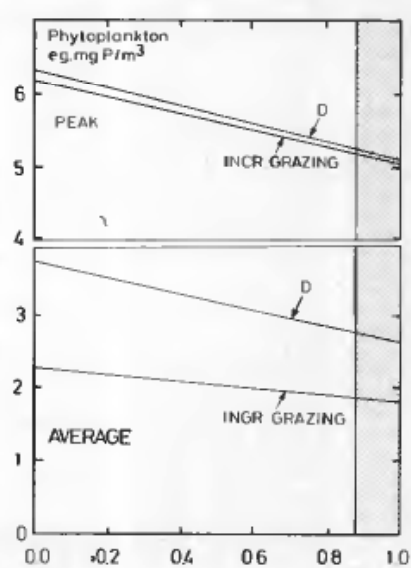

c)

Figure 9. Phytoplankton biomass as a function of river water discharge. Average and peak values. (a) Different schemes for thermocline movement during stratified period. $D$ designates a deep thermocline eroding from 20 to $40 \mathrm{~m}$ depth. $M$ designates a medium depth thermocline, eroding from 15 to $30 \mathrm{~m}$ depth. $\mathrm{S}$ designates a shallow thermocline eroding from 10 to $20 \mathrm{~m}$ depth. Shaded area indicates probable range for variation in total water flow. $(b)$ Light extinction associated with river through-flow. TURB $=35$. D is reference curve, corresponds to curve D in Fig. $9(a)$. Compare Fig. 7 and see also the text. (c) Increased grazing. $\omega=0 \cdot 5, M M=0 \cdot 1$. Compare Fig. $8(a)$, and see also the text. 
phytoplankton biomass, and this effect is only slightly dependent on water throughflow. The peak biomass is nearly independent of grazing pressure.

In the following simulation series we have approximated the river flow as one broad peak as indicated in Fig. $2(c)$ and shifted the time for peak flow throughout the year. Results are given in Fig. 10 for a peak and average phytoplankton biomass. Three cases are considered shallow thermocline at 10-20 m, deep thermocline at $20-40 \mathrm{~m}$, and a case with deep thermocline and the turbidity depending on river flow. It is seen that the flow peak gives lowest biomass when it occurs during the stratified period, relatively more for the peak value than for the average. Of special importance is the simulated case where river flow also causes light extinction. The reduction is then dramatic. When peak water flow occurs in July it will also cause a shift in peak phytoplankton biomass from the end of July to the beginning of September (not shown).

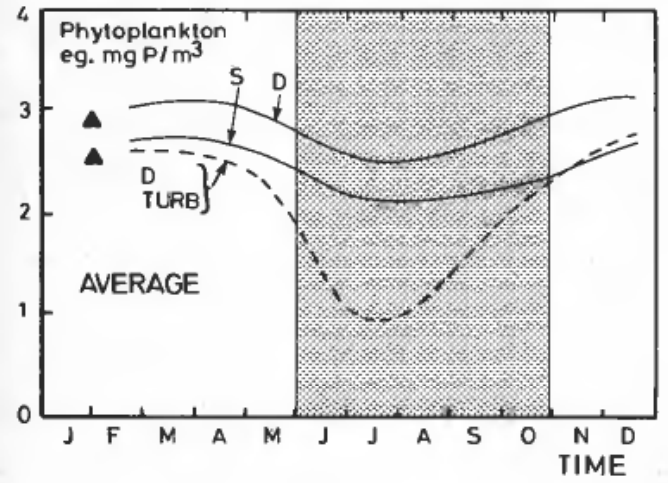

(a)

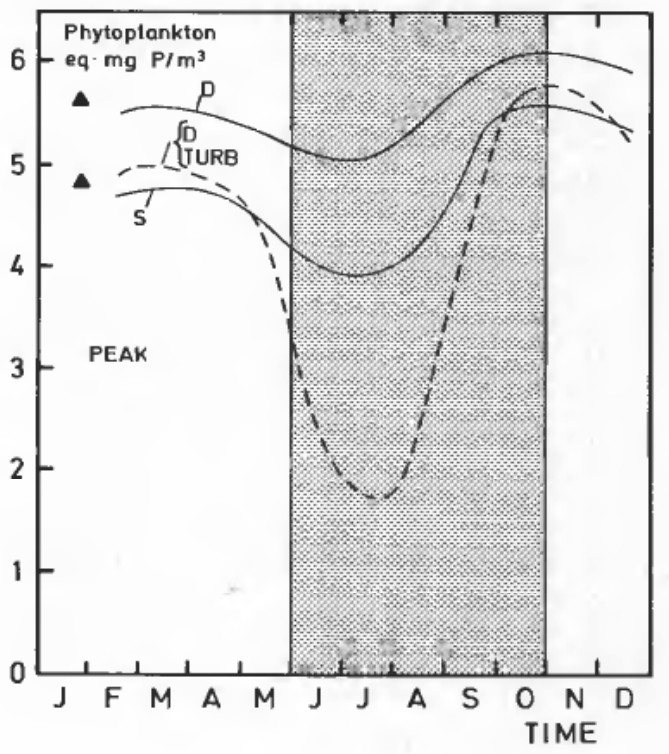

(b)

Figure 10. Phytoplankton biomass as a function of time for peak river flow. Compare Fig. 2 (c). (a) Average. (b) Peak. D designates deep thermocline eroding from 20 to $40 \mathrm{~m}$ depth. S designates shallow thermocline eroding from 10 to $20 \mathrm{~m}$ depth. D, TURB designates deep thermocline and light extinction associated with river discharge. $\boldsymbol{\Delta}$ is the result when river flow is averaged evenly over the year. Shaded area indicates probable range for beginning and end of peak flow.

\section{Discussion and conclusion}

The present simulation model has been run with data which approximate the main basin of Lake Mjøsa and the external forces acting on the lake system in 1976. The system is strongly susceptible to external pulses occurring with a period of one year, e.g. stratification, peaks in nutrient inputs and water throughflow. The correspondence between simulated results and observations of phytoplankton and nutrient time series is fairly good, and indicates that the model can be used to explore further the effects of variations in external factors. The simulations may also be considered as a type of sensitivity analysis. 
Three processes which may change the phytoplankton standing crop have been examined: nutrient load, nutrient injection depths and water inflow. The first two processes have been studied under three different assumptions on how vertical water exchange occurs. The results indicate that hypolimnetic injection of nutrients from point sources, like the discharge from sewage plants, may be important for reducing eutrophication. However, this is only significant if the vertical exchange is very low. For example, the smooth erosion of the thermocline in Lake Mjøsa may be sufficient to decrease substantially the efficiency of the method for this lake.

The results for river flow indicate that the timing of peak flow is a more important parameter with regard to phytoplankton biomass than the flow volume. In the first case changes in river flow may account for changes of about $6 \%$ in peak biomass value, whereas shifting in peak timing may potentially cause changes up to $40 \%$. However, the thermocline lies probably somewhere between the shallow and deep positions depicted and the minimum river flow during the stratified period will scarcely reach low October-November values as implemented in the simulation run, see Fig. $2(c)$. Thus we believe that the actual upper bracket for increase in phytoplankton peak biomass due to shift in river flow may be about $15-20 \%$. To validate the model further, we are planning to simulate phytoplankton growth during several years where nutrient load and river discharge are known. When the effects of increased light extinction caused by suspended particles are added, substantially greater changes may occur. However, these effects are only realized in the NW parts of the lake, close to the main river inlet. The effects of grazing introduce a complex dynamic relationship between species of the ecosystem. It may potentially change the system considerably, but too little is known of this interaction to assess the probability of such occurrences.

The results reported may be useful in formulating a 'best available assessment' of the impact of several abiotic factors on the eutrophication of Lake Mjøsa. It can also be seen as an attempt to identify factors which should be given a closer study in further observations of the Lake Mjøsa ecosystem.

The model is now also being used in an attempt to assess the contribution of fish excretion to the phosphorus budget of the small lake Gjersjøen, Norway, and we are extending the model to incorporate constructs for additional ecological processes which will contribute to a better description of lake ecosystems.

\section{ACKNOWLEDGMENTS}

I am grateful to Marit Fossdal, Hans Holtan, Torulv Tjomsland and Arve M. Tvede for providing me with data on Lake Mjøsa. Marit Fossdal, Hans Holtan, Yngvar Maehlum and Hans Martin Seip have read various drafts of the manuscript and been very helpful with advice and comments. Thanks are also due to an anonymous referee.

\section{REFERENCES}

Bacca, R. G., Gasperino, A. F., Brandstetter, A., and Myhres, A. S. (1977). Water quality models for municipal water supply reservoirs. Part 2. Battelle, Pacific Northwest Laboratories, Richland, Washington, p. 121.

Berge, F. S., Jacobsen, P., Rye, H., and og Thendrup, A. (1980). The assessment of some physical properties in Lake Mjøsa based on measurements of water currents and temperature in 1978. Report No. 608013.20 from Norwegian Hydrodynamic Laboratories (in Norwegian). p. 141. 
Berliand, T. G. (1960). Climatological methods of total radiation. Meteor. Gidrol., 6, 9-12.

Burns, N. M., and Rosa, F. (1980). In situ measurements of the settling velocity of organic carbon particles and 10 species of phytoplankton. Limnol. Oceanogr., 25, 855-864.

Canale, R. P., De Palma, L., and Vogel, A. H. (1976). A plankton based food web model for Lake Michigan. In: R. P. Canale (Editor), Modeling Biochemical Processes in Aquatic Ecosystems (Ann Arbor: Science), pp. 33-74.

Di Toro, D. M. (1980). Applicability of cellular equilibrium and Monod theory to phytoplankton growth kinetics. Ecol. Modelling, 8, 201-218.

Duton, J. A., and Bryson, R. A. (1962). Heat flux in Lake Mendota. Limnol. Oceanogr., 7, 80-96.

EBENHÖH, W. (1980). A model of the dynamics of plankton patchiness. Modeling, Identification and Control, 1, 69-91.

HAMm, A., and KUCKLENTZ, V. (1980). Effects of hydraulic changes on the eutrophication of an alpine lake. SIL-Congress Kyoto (Japan), 24-31 August.

Holtan, H. (1977). The Lake Mjøsa Project. Progress Report No. 7. Investigations 1976 (in Norwegian) (Norwegian Institute for Water Research), p. 45.

Holtan, H. (1978). Eutrophication of Lake Mjøsa in relation to the pollutional load. Verh. Internat. Verein. Limnol., 20, 734-742.

Holtan, H. (1979). The Lake Mjesa Project. Main report for the years 1971-76 (in Norwegian) (Norwegian Institute for Water Research), p. 176.

IMBODEN, D. M. (1974). Phosphorus model of Lake eutrophication. Limnology and Oceanography, 19, 297-304.

LORENZEN, M. W. (1980). Use of chorophyll-Secchi disk relationship. Limnol. Oceanogr., 25, 371-372.

Megard, R. O., Combs, W. S., JR., Smith, P. D., and Knoll, A. S. (1979). Attenuation of light and daily integral rates of photosyntheses attained by planktonic algae. Limnol. Oceanogr., 24, 1038-1050.

Megard, R. O., Settles, J. C., Boyer, H. A., and Combs, W. S., JR. (1980). Light, Secci disks, and trophic states. Limnol. Oceanogr., 25, 373-377.

Parsons, T. R., and Takahashi, M. (1973). Biological Oceanographic Processes (Oxford: Pergamon Press), p. 186.

Prepas, E. E., and Rigler, F. H. (1980). A test of a simple model to predict short-term changes in the phosphorus concentration in lake water. Paper presented to SILCongress, Kyoto (Japan), 24-31 August.

Reshikin, S. J., and KNAUER, G. A. (1979). Light stimulation of phosphate uptake in natural assemblages of phytoplankton. Limnol. Oceanogr., 24, 1121-1124.

Scavia, D. (1980). An ecological model of Lake Ontario. Ecol. Modelling, 8, 49-78.

SCHINDLER, D. W., RuszcZYNSKı, T., and FEE, E. J. (1980). Hypolimnion injection of nutrient effluents as a method for reducing eutrophication. Can. J. Fish. Aquat. Sci., 37, 320-327.

SCHOONER, J. L., and Di Toro, D. M. (1980). Differential phytoplankton sinking- and growth rates. An eigenvalue analysis. Ecol. Modelling, 9, 233-245.

SEIP. K. (1980 a). A mathematical model of the Lake Mjøsa ecosystem. To be published in the Proceedings from the Second International Conference on the State-of-the-art in the Ecological Modelling, Liege (Belgium), 18-24 April.

SEIP, K. (1980 b). A simulation study of the impact of nutrient load, nutrient injection depths and water inflow regulation on a mesotrophic lake. SIL-Congress, Kyoto (Japan), 24-31 August.

SмITH, R. A. (1980). The theoretical bases for estimating phytoplankton production and specific growth rate from chlorophyl, light and temperature data. Ecol. Modelling, 10, 243-264.

THENDRUP, A. (1978). Which changes in the temperature and flow conditions of Lake Mjøsa can be anticipated as a consequence of the Jotunheimen river regulations? (in Norwegian). Vann, 4, 325-338.

Wetzel. R. G. (1975). Limnology (Philadelphia: W. B. Saunders). 